\title{
Effect of the Addition of Diammonium Citrate to $\alpha$-Cyano-4-Hydroxycinnamic Acid (CHCA) Matrix for the Detection of Phosphorylated Peptide in Phosphorylation Reactions Using Cell and Tissue Lysates
}

\author{
Jeong-Hun Kang, ${ }^{\text {a,b }}$ Riki Toita, a,b Jun Oishi, ${ }^{\text {a,b }}$ Takuro Niidome, \\ and Yoshiki Katayama, ${ }^{a, b, c}$ \\ a CREST, Japan Science and Technology Corporation, Kawaguchi, Japan \\ ${ }^{\mathrm{b}}$ Department of Applied Chemistry, Faculty of Engineering, Kyushu University, Fukuoka, Japan \\ c Center for Future Chemistry, Kyushu University, Fukuoka, Japan
}

The ionization of phosphorylated peptides is usually suppressed by non-phosphorylated peptides when $\alpha$-cyano-4-hydroxycinnamic acid (CHCA) is used as a matrix for matrixassisted laser desorption/ionization-time-of-Flight (MALDI-TOF) mass spectrometry analysis. In the present study, we examined the effect of diammonium citrate addition to the CHCA matrix on the detection of phosphorylated peptides. Substrates for protein kinase C (PKC) and c-Src were synthesized and phosphorylated by reaction with cell and tissue lysate samples. The addition of diammonium citrate to the CHCA matrix increased the sensitivity for distinguishing phosphorylated peptides from background noise. However, the effect depended on substrate concentration. (J Am Soc Mass Spectrom 2007, 18, 1925-1931) (c) 2007 American Society for Mass Spectrometry

$\mathrm{P}$ rotein phosphorylation is one of the most important post-translational modifications, as it regulates cellular functions through information processing [1-3]. In this context, the determination of phosphorylated peptides using mass spectrometry has attracted much attention in many biological and pharmacological fields. The detection limit for phosphorylated peptides in mass analysis is dependent on several factors such as ionization efficiency, mass, and hydrophobicity. Matrix-assisted laser desorption/ionization (MALDI) is relatively tolerant of salts and buffer components such as sodium chloride and phosphate, particularly when compared with most other forms of mass spectrometric ionization. However, when the concentration of these components is high, crystal formation may be prevented and ionization impeded $[4,5]$. Moreover, cell lysates contain many biomolecules such as proteins and lipids, and relatively high concentrations of contaminants including buffers. These components can also prevent crystal formation and interfere with ionization.

For example, previous studies suggested that the ionization of phosphorylated peptides is usually suppressed by unphosphorylated peptides when $\alpha$-cyano-

Address reprint requests to Dr. Y. Katayama, Department of Applied Chemistry, Faculty of Engineering, Kyushu University, 744 Moto-oka, Nishi-Ku, Fukuoka 819-0395, Japan. E-mail: ykatatcm@mbox.nc. kyushu-u.ac.jp 4-hydroxycinnamic acid (CHCA) is used as a matrix [6-10]. Several attempts have been made to reduce this effect [6-10]. Among them, the addition of diammonium citrate to the CHCA matrix can increase the peak intensity of the phosphorylated peptides or proteins $[6$, 10]. This may be a simple and useful method to identify the phosphorylated peptide or protein for certain protein kinases. However, there is very little data concerning the application of diammonium citrate in matrices for the detection of phosphorylated peptides from cell and tissue samples.

In the present study, two substrates for protein kinase $\mathrm{C}$ (PKC) $\alpha$ and $\mathrm{c}$-Src were used to test and optimize the effectiveness of diammonium citrate to enhance our ability to detect phosphorylated peptides from cell and tissue samples. PKC, a calcium- and phospholipid-dependent serine/threonine kinase consisting of 11 isozymes [11-13], appears to be involved in the signal transduction response to a variety of hormones and growth factors. Certain isozymes such as PKC $\alpha$, are considered to play an important role in carcinogenesis and tumor growth [14].

c-Src is a non-receptor tyrosine kinase that is known to increase in a multitude of human tumors, including breast, stomach, colon, and prostate. Activated c-Src can phosphorylate the human epidermal growth factor receptor (HER), which is the prototype of a family that consists of four members (epidermal growth factor 
receptor/HER1, neu/erbB2/HER2, erbB3/HER3, and erbB4/HER4), leading to tumor cell growth and proliferation [3, 15-17].

Thus, the phosphorylation of serine, threonine, and tyrosine residues by such protein kinases has an important influence on diverse biological phenomena, including signal transduction, cell division and motility, apoptosis, and carcinogenesis [3, 11-19].

\section{Experimental}

\section{Peptide Synthesis}

Substrates for PKC $\alpha$ (FKKQGSFAKKK; MW, 1336.8) and c-Src (CXXEEIYGEFD, where $X$ connotes the group [- $\left.\left.\mathrm{NH}\left(\mathrm{CH}_{2} \mathrm{CH}_{2} \mathrm{O}\right)_{2} \mathrm{CH}_{2} \mathrm{CO}-\right] ; \mathrm{MW}, 1392.5\right)$ were synthesized using an automatic peptide synthesizer according to standard Fmoc-chemistry. The latter peptide can be fixed to the slide glass for application as a peptide array. The Cys residue and linkages are known to have no effect on the phosphorylation of the substrate [20,21]. After trifluoroacetic acid (TFA) cleavage, the peptide was purified on an Inertsil ODS-3 column $(250 \times 20$ $\mathrm{mm}, 3.5 \mu \mathrm{m}, \mathrm{GL}$ Sciences Inc., Tokyo, Japan) using a BioCAD perfusion chromatography system (Ikemoto Scientific Technology Co., Tokyo, Japan) under a linear A-B gradient at a flow rate of $8 \mathrm{~mL} / \mathrm{min}$, where eluent A was $0.1 \%$ TFA in water and eluent B was $0.1 \%$ TFA in acetonitrile (HPLC grade).

\section{Sample Preparation for MALDI Time-of-Flight (TOF) Mass Spectrometry}

The $\alpha$-cyano-4-hydroxycinnamic acid (CHCA) matrix $(10 \mathrm{mg} / \mathrm{mL})$ was prepared in $50 \%$ water/acetonitrile and $0.1 \%$ TFA. The modified CHCA matrix included diammonium citrate $(5 \mathrm{mg} / \mathrm{mL})$. The matrix and sample were mixed in ratios of 1:1, 2:1, 3:1, 4:1, and 5:1. A total volume of $1 \mu \mathrm{L}$ of the analyte/matrix mixture was applied on the sample plate and allowed to dry to induce crystallization.

\section{MALDI-TOF Mass Spectrometry}

Experiments were conducted using a Voyager DE RP BioSpectrometry Workstation (Applied Biosystems, Framingham, MA) in positive or negative ion reflectron mode. The accelerating voltage was $20 \mathrm{kV}$ with a $100-\mathrm{ns}$ extraction delay time. Typically, 100 laser shots were averaged to improve the signal-to-noise ratio. All spectra were analyzed using Data Explore software (Applied Biosystems). Triplicate samples were prepared and each was analyzed twice. Means of the phosphorylation ratio obtained from three spots selected manually on the crystals were used as results for assay purposes. The phosphorylation ratio is defined as the ratio of ion intensities for the phosphorylated to unphosphorylated material, and this was calculated as described previously [22]

\section{Phosphorylation of Substrates with PKC $\alpha$} and c-Src Enzyme

Phosphorylation of the PKC $\alpha$ substrate was carried out in $10 \mu \mathrm{L}$ of buffer [20 mM Tris- $\mathrm{HCl}$ at $\mathrm{pH} 7.5,10 \mathrm{mM}$ $\mathrm{MgCl}_{2}, 0.5 \mathrm{mM} \mathrm{CaCl}, 100 \mu \mathrm{M}$ adenosine triphosphate (ATP), $2 \mu \mathrm{g} / \mathrm{mL}$ diacylglycerol (DAG), and $2 \mu \mathrm{g} / \mathrm{mL}$ phosphatidylserine (PS)] containing $30 \mu \mathrm{M}$ synthetic peptide and $0.1 \mu \mathrm{g} / \mathrm{mL}$ of PKC $\alpha$.

For c-Src, $10 \mu \mathrm{L}$ of buffer $(20 \mathrm{mM}$ Tris- $\mathrm{HCl}$ at $\mathrm{pH} 7.5$, $10 \mathrm{mM} \mathrm{MgCl}$, and $100 \mu \mathrm{M}$ ATP) containing $30 \mu \mathrm{M}$ synthetic peptide and $0.1 \mu \mathrm{g} / \mathrm{mL}$ of c-Src. After incubation for $60 \mathrm{~min}$ at $37^{\circ} \mathrm{C}$, the sample was analyzed by MALDI-TOF mass spectrometry.

\section{Cell Culture and Lysate Preparation}

B16 melanoma cells were maintained in Dulbecco's modified Eagle's medium supplemented with 10\% fetal bovine serum, penicillin $(100 \mathrm{U} / \mathrm{mL})$, streptomycin $(100$ $\mu \mathrm{g} / \mathrm{mL})$, and amphotericin B $(0.25 \mu \mathrm{g} / \mathrm{mL})$. The cells were kept in a humidified atmosphere containing 5\% $\mathrm{CO}_{2}$ and $95 \%$ air at $37{ }^{\circ} \mathrm{C}$. The cultured cell was then scraped and lysed in $20 \mathrm{mM}$ Tris-HCl buffer ( $\mathrm{pH}$ 7.5) by sonication. The sample was centrifuged at $5000 \times g$ for $60 \mathrm{~min}$ at $4{ }^{\circ} \mathrm{C}$. The supernatant $(200 \mu \mathrm{g} / \mathrm{mL})$ was used as a whole cell lysate (membrane and cytosol fractions) for the phosphorylation reaction.

For the detection of total protein concentration, standard working bovine serum albumin (BSA) solutions of 0.125 to $2 \mathrm{mg} / \mathrm{mL}$ were prepared by diluting aliquots of the stock solution $(10 \mathrm{mg} / \mathrm{mL})$ in water. A $10-\mu \mathrm{L}$ volume of the standard BSA solution was mixed with 1 $\mathrm{mL}$ of Bio-Rad Protein assay Dye reagent (BIO-RAD Lab., Hercules, CA) and detected by the absorbance at $595 \mathrm{~nm}$. Calibration curves for concentrations ( 0.125 to 2 $\mathrm{mg} / \mathrm{ml}$ ) versus detector responses (absorbance at 595 $\mathrm{nm}$ ) were obtained using a linear regression program. The correlation coefficients of absorbance to concentration were $>0.998$. A $10-\mu \mathrm{L}$ volume of cell extract was mixed with $1 \mathrm{ml}$ of Bio-Rad protein assay dye reagent. The protein concentration was detected using a UV system, and calculated from the corresponding calibration curve.

\section{Tissue Lysate Preparation}

In the present study, all animal studies were performed in accordance with the Guidelines for Animal Experiments, set out by the Kyushu University.

Male 5-wk old BALB/c mice, weighing $20 \mathrm{~g}$, were used in this study. The dorsal side was inoculated subcutaneously with $1 \times 10^{6}$ B16 melanoma cells per $100 \mu \mathrm{L}$ of Hanks' balanced salt solution (Gibco) per animal. Tumors were allowed to grow to a mean diameter of $\sim 0.7$ to $1.0 \mathrm{~cm}$.

Tissue lysates for PKC were obtained from excised tumors grown in mice. After the tumors were weighed, they were homogenized in $10 \mathrm{~mL}$ of buffer [20 mM 


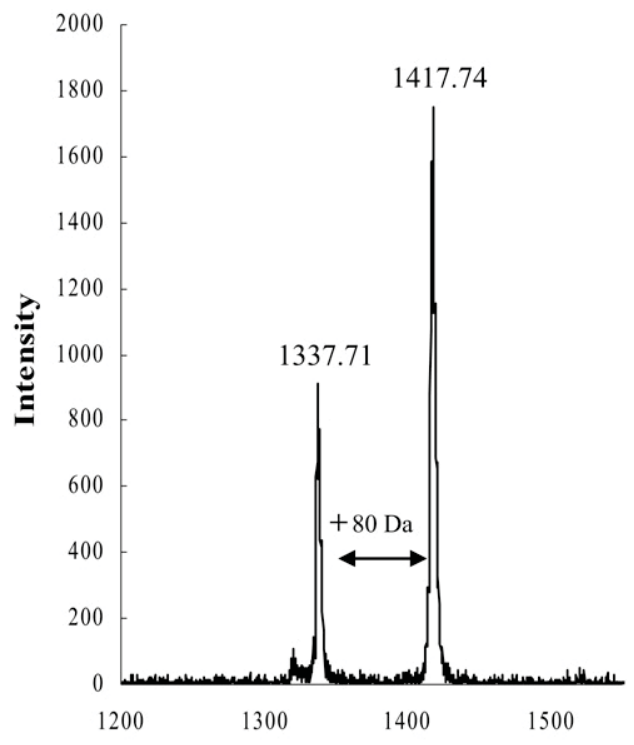

(a)

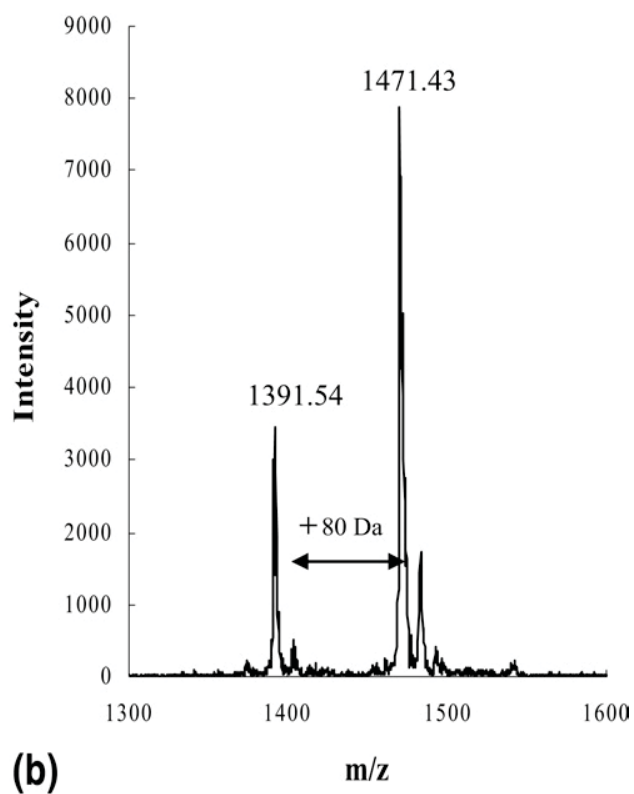

Figure 1. Typical MALDI-TOF mass spectra obtained from phosphorylation of the substrates for PKC $\alpha$ (a) or c-Scr (b) with each target enzyme. An increase of +80 Da was identified for the phosphorylated peptide.

Tris- $\mathrm{HCl}, \mathrm{pH} 7.5,250 \mathrm{mM}$ sucrose, and protease inhibitor (Roche, Tokyo, Japan)]. The homogenate was centrifuged at $1000 \times g$ at $4{ }^{\circ} \mathrm{C}$ for $10 \mathrm{~min}$ and the supernatant was removed. After washing the precipitate with $5 \mathrm{~mL}$ of buffer and re-centrifuging, $1 \mathrm{~mL}$ of buffer was added and the precipitate further sonicated for $30 \mathrm{~s}$. After sonication of the homogenate, the samples were centrifuged at $5000 \times g$ at $4{ }^{\circ} \mathrm{C}$ for $15 \mathrm{~min}$, and the resulting supernatant $(200 \mu \mathrm{g} / \mathrm{mL})$ was used as a whole lysate sample for the phosphorylation reactions. Total protein concentration was detected with the aid of a Bio-Rad protein assay dye reagent. The lysate of normal skin tissue was also prepared according to the same method.

For c-Src, brain tissue was homogenized in $10 \mathrm{~mL}$ of buffer [20 mM Tris- $\mathrm{HCl}$, pH 7.5, $250 \mathrm{mM}$ sucrose, and protease inhibitor (Roche)]. The homogenate was centrifuged at $100,000 \times g$ at $4{ }^{\circ} \mathrm{C}$ for $60 \mathrm{~min}$ and the supernatant was removed. After washing the precipitate with $5 \mathrm{ml}$ of buffer and re-centrifuging, $1 \mathrm{~mL}$ of buffer with $0.2 \%$ Triton $\mathrm{X}-100$ was added and the precipitate further sonicated for $30 \mathrm{~s}$. After sonication of the homogenate, the samples were centrifuged at $100,000 \times g$ at $4{ }^{\circ} \mathrm{C}$ for $30 \mathrm{~min}$, and the supernatant $(200 \mu \mathrm{g} / \mathrm{mL})$ was used for the phosphorylation reaction.

\section{Statistical Analysis}

Statistical analysis consisted of significance testing of the differences between means by Student's $t$-test at the following significance levels: $P<0.1$ and $P<0.5$.

\section{Results and Discussion}

\section{Phosphorylation of Two Substrates by Target Enzyme}

In a previous study, we found that the substrate (FKKQGSFAKKK) showed a higher phosphorylation ratio on $\mathrm{PKC}_{\alpha}$ [22]. Here, the same substrate was used in the phosphorylation reaction for PKC $\alpha$. A substrate specific to c-Src (EEIYGEFD) was synthesized according to a study reported by Songyang et al. [23].

Phosphorylation of the two substrates by each target enzyme was identified by an increase in the $m / z$ value of +80 Da (Figure 1) [6-10]. In the case of c-Src, no phosphorylated peak was observed using positive ion reflectron mode, which may be a result of the substrate for c-Src containing four anionic amino acid residues (E and D). On the other hand, detection using the negative ion reflectron mode revealed a phosphorylated peak.

\section{Suitable Ratio of Matrix and Sample}

In the present study, CHCA was used as a matrix for analysis. The 1:1 volume ratio of CHCA matrix and melanoma cell lysate sample prevented crystal formation and interfered with the ionization. These results may be caused by known or suspected contaminants and biomolecules such as Tris base, proteins, and lipids. Two simple methods for reducing these contaminants involve washing the samples with 5 to $10 \mu \mathrm{L}$ of either distilled deionized water or $0.1 \%$ TFA. This process also serves to dilute the samples [4]. Since the former method can often lead to sample losses, the dilution method was used in this study. When the ratio of 
Table 1. Change of phosphorylation ratio after the addition of activator and/or cofactors to the cell reaction lysate

\begin{tabular}{|c|c|}
\hline Activator and/or cofactor & $\begin{array}{l}\text { Phosphorylation } \\
\text { ratio }(\%) \\
(n=3)\end{array}$ \\
\hline $\mathrm{Mg}^{2+}+\mathrm{ATP}$ & $28.5 \pm 2.1$ \\
\hline $\mathrm{Mg}^{2+}+\mathrm{ATP}+\mathrm{Ca}^{2+}$ & $24.8 \pm 3.6$ \\
\hline $\mathrm{Mg}^{2+}+\mathrm{ATP}+\mathrm{PS}$ & $27.0 \pm 3.6$ \\
\hline $\mathrm{Mg}^{2+}+\mathrm{ATP}+\mathrm{PS}+\mathrm{Ca}^{2+}$ & $26.2 \pm 5.6$ \\
\hline $\mathrm{Mg}^{2+}+\mathrm{ATP}+\mathrm{DAG}$ & $45.5 \pm 2.3$ \\
\hline $\mathrm{Mg}^{2+}+\mathrm{ATP}+\mathrm{DAG}+\mathrm{Ca}^{2+}$ & $46.6 \pm 1.1$ \\
\hline $\mathrm{Mg}^{2+}+\mathrm{ATP}+\mathrm{DAG}+\mathrm{PS}$ & $47.9 \pm 5.0$ \\
\hline $\mathrm{Mg}^{2+}+\mathrm{ATP}+\mathrm{DAG}+\mathrm{PS}+\mathrm{Ca}^{2+}$ & $57.2 \pm 4.8$ \\
\hline
\end{tabular}

CHCA to sample was increased more than 2-fold (2:1 to $5: 1)$, the tolerance for the contaminants was enhanced and crystal formation and ionization occurred. A 5:1 ratio of matrix to sample achieved the best invariable peaks of the phosphorylated peptide from the whole range of the plate (data not shown). In the present study, therefore, a 5:1 ratio of matrix to sample was used for detecting phosphorylated peptides in the cell and tissue lysates.

Moreover, MALDI-TOF mass spectrometry can be used to analyze a wide range of peptide concentrations, from $10^{-4} \mathrm{M}(100 \mathrm{pmol} / \mu \mathrm{L})$ to $10^{-8} \mathrm{M}(10 \mathrm{fmol} / \mu \mathrm{L})$ [4]. In the present study, the concentration of peptide (5 $\mu \mathrm{M})$ in the ratio $5: 1$ is included in this range.

\section{Phosphorylation of PKC Substrate with Cell Lysate}

After phosphorylation of the PKC $\alpha$ substrate with the cell lysate of B16 melanoma, no peaks of the phosphorylated peptide were found. These results may be caused by a loss of indispensable factors for the PKC $\alpha$ phosphorylation reaction during cell lysate preparation. PKC $\alpha$ consists of a single polypeptide chain with an amino-terminal regulatory region and a carboxylterminal catalytic region. The regulatory region of PKC $\alpha$ contains an auto-inhibitory domain (pseudosubstrate) and two membrane-targeting domains (C1 and $\mathrm{C} 2$ ). The $\mathrm{C} 1$ domain binds to diacylglycerol (DAG), while the $\mathrm{C} 2$ domain contains many acidic amino acids that take part in $\mathrm{Ca}^{2+}$ binding. The catalytic region contains two domains (C3 and C4). The C3 domain contains the adenosine triphosphate (ATP)-binding motif while the $\mathrm{C} 4$ domain binds to the substrate. For substrate phosphorylation by PKC $\alpha, \mathrm{DAG}, \mathrm{Ca}^{2+}$, and ATP were found to be indispensable factors [11-13, 19]. A phosphatidylserine (PS)-binding domain is not found in PKC $\alpha$, but PS shows synergistic activation with DAG and $\mathrm{Ca}^{2+}$ during phosphorylation [11-13]. DAG is a basic component of membranes and serves as hydrophobic anchors in PKC and membrane interaction. It is produced in the hormone-sensitive phosphatidylinositol system. Active phospholipase C cleaves plasma membrane lipid phosphatidylinositol-4,5-bisphosphate into DAG and inositol-1,4,5-trisphosphate [11, 24, 25]. On the other hand, PS is an acidic membrane phospholipid and is produced by the displacement of cytidine monophosphate through nucleophilic attack by the hydroxyl group of serine [11, 24, 25].

Therefore, we investigated the indispensable factors for the PKC $\alpha$ phosphorylation reaction. Phosphorylation did not occur in the absence of $\mathrm{Mg}^{2+}$ and ATP. The addition of only ATP did not lead to substrate phosphorylation (data not shown). However, the addition of both ATP and $\mathrm{Mg}^{2+}$ was sufficient to initiate the PKC phosphorylation reaction affording a peak in the MS spectrum corresponding to the phosphorylated peptide (Table 1). Many enzymes require both $\mathrm{Mg}^{2+}$ and ATP for their activity because the true substrate for enzymes is not $\mathrm{ATP}^{4-}$, but an ATP-Mg ${ }^{2-}$ complex $[26,27]$. Moreover, the addition of $\mathrm{Ca}^{2+}$ and/or PS in the presence of ATP and $\mathrm{Mg}^{2+}$ had no effect on the phosphorylation reaction (data not shown). However, the addition of DAG in the presence of ATP and $\mathrm{Mg}^{2+}$ accelerated the reaction. The obtained peak intensity was higher (about two times) than that observed for $\mathrm{Ca}^{2+}$ and/or PS addition (Table 1). These results are closely related to the DAG function for the PKC $\alpha$ phosphorylation reaction. DAG is a membrane lipid and its binding to the $\mathrm{C} 1$ domain of PKC $\alpha$ activates PKC $\alpha$. However, the PKC $\alpha$ that exists in the cytosol is inactive [11-13]. In the present study, the total cell lysate (membrane and cytosol fractions) was used for the phosphorylation reaction of PKC $\alpha$. Therefore, the addition of DAG to these lysate samples led to activation of the PKC $\alpha$ present in the cytosol, resulting in an increase in the phosphorylation ratio.

Table 2. Ionization efficiencies of the phosphorylated and non-phosphorylated peptides

\begin{tabular}{|c|c|c|c|c|}
\hline \multirow[b]{3}{*}{ Peptide concentration $(\mu \mathrm{M})$} & \multicolumn{4}{|c|}{ Intensity (\%) $(n=3)$} \\
\hline & \multicolumn{2}{|c|}{ Without diammonium citrate } & \multicolumn{2}{|c|}{ With diammonium citrate } \\
\hline & Peptide & Phosphorylated peptide & Peptide & Phosphorylated peptide \\
\hline 7.5 & 100 & $60.3 \pm 3.8$ & 100 & $26.7 \pm 5.7$ \\
\hline 15 & 100 & $69.3 \pm 4.9$ & 100 & $55.3 \pm 10$ \\
\hline 30 & 100 & $76.7 \pm 2.1$ & 100 & $82.4 \pm 2.1$ \\
\hline 60 & 100 & $75.3 \pm 2.5$ & 100 & $60.3 \pm 6.8$ \\
\hline 120 & 100 & $76.1 \pm 2.7$ & 100 & $48.2 \pm 5.8$ \\
\hline 240 & 100 & $76.8 \pm 2.1$ & 100 & $38.7 \pm 5.1$ \\
\hline
\end{tabular}



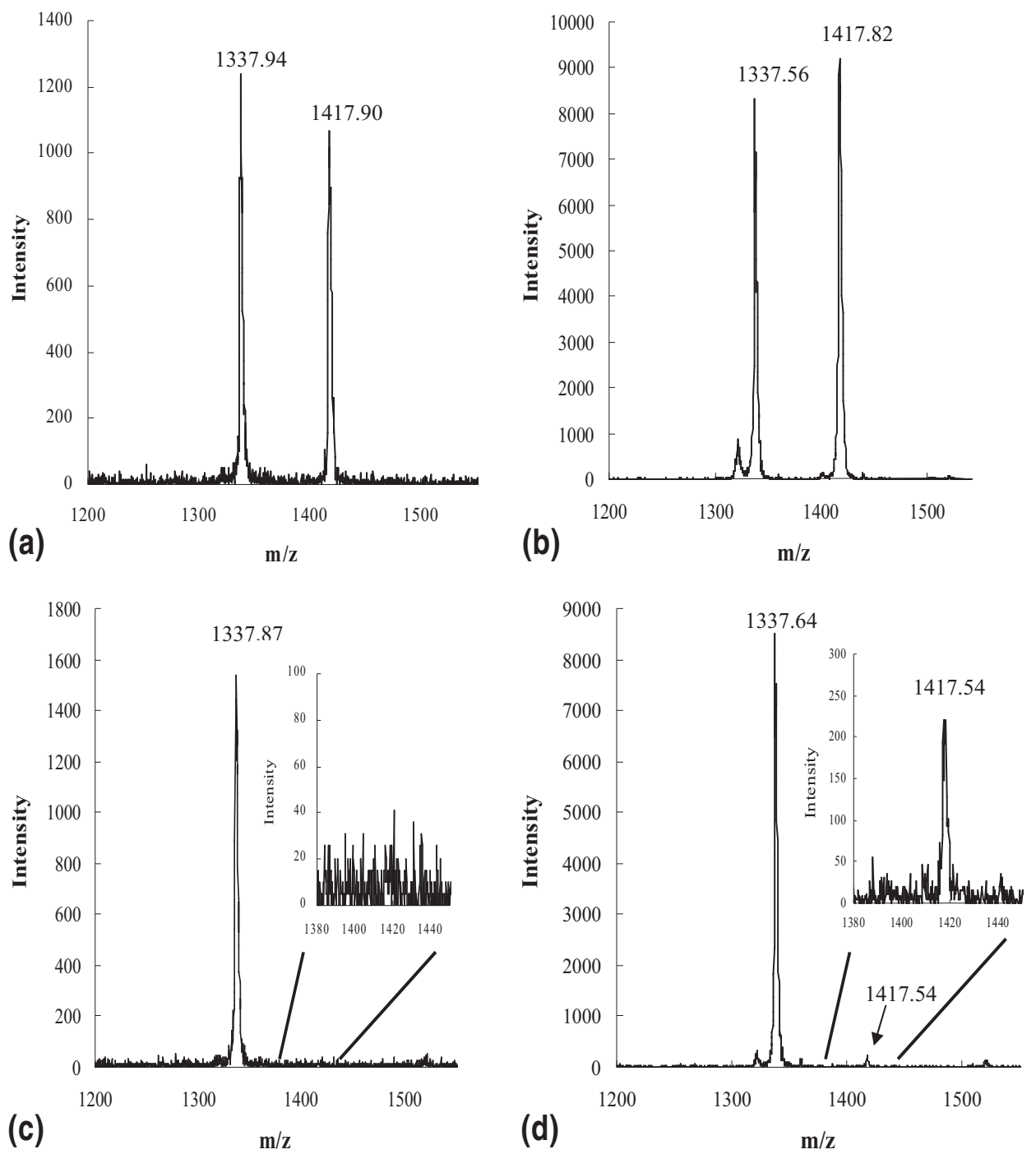

Figure 2. Typical MALDI-TOF mass spectra obtained from phosphorylation of the PKC $\alpha$ substrate with melanoma (a) and (b); normal skin tissue lysate (c) and (d); with (b) and (d) or without (a) and (c) diammonium citrate.

Since c-Src had two domains, one for substrate binding and the other for binding the ATP- $\mathrm{Mg}^{2-}$ complex [15-17], phosphorylation peaks were also found on addition of ATP and $\mathrm{Mg}^{2+}$ (data not shown). These results mean that ATP can be lost easily during lysate preparation.

\section{Addition Effect of Diammonium Citrate to Matrix}

To identify changes in the peak intensity with varying peptide or phosphorylated peptide concentration, we synthesized two peptides, FKKQGSFAKKK and the phosphorylated peptide (FKKQGphosphoSFAKKK) containing phosphorylated Ser instead of the serine residue. Two peptide solutions were mixed in a ratio of 1:1 (vol/vol) at concentrations of 7.5, 15, 30, 60, 120, and $240 \mu \mathrm{M}$, then combined with CHCA in the presence or absence of diammonium citrate, and finally analyzed by MALDI-TOF mass spectrometry. In the absence of diammonium citrate, the intensity (about $76 \%$ of the non-phosphorylated peptide peak intensity) of the phosphorylated peptide was similar to that in the range of 30 to $120 \mu \mathrm{M}$. However, decreases in the intensity of the phosphorylated peptide by $15 \%$ and $7 \%$ were observed for peptide solution concentrations of 7.5 and 15 $\mu \mathrm{M}$, respectively, when compared with that in the range of 30 to $120 \mu \mathrm{M}$. In the presence of diammonium citrate $(5 \mathrm{mg} / \mathrm{mL})$, the largest peak intensity $(>80 \%$ of the non-phosphorylated peak) of the phosphorylated peptide was obtained from a peptide solution concentration of $30 \mu \mathrm{M}$, and then the peak intensity decreased gradually with an increase in the peptide concentration. On the other hand, the intensity at 7.5 and $15 \mu \mathrm{M}$ averaged $27 \%$ and $55 \%$, respectively (Table 2 ).

Moreover, we examined whether there is a change in the phosphorylation ratio by the CHCA matrix, prepared with and without diammonium citrate, after the phosphorylation reaction of peptide substrates $(15,30$, 

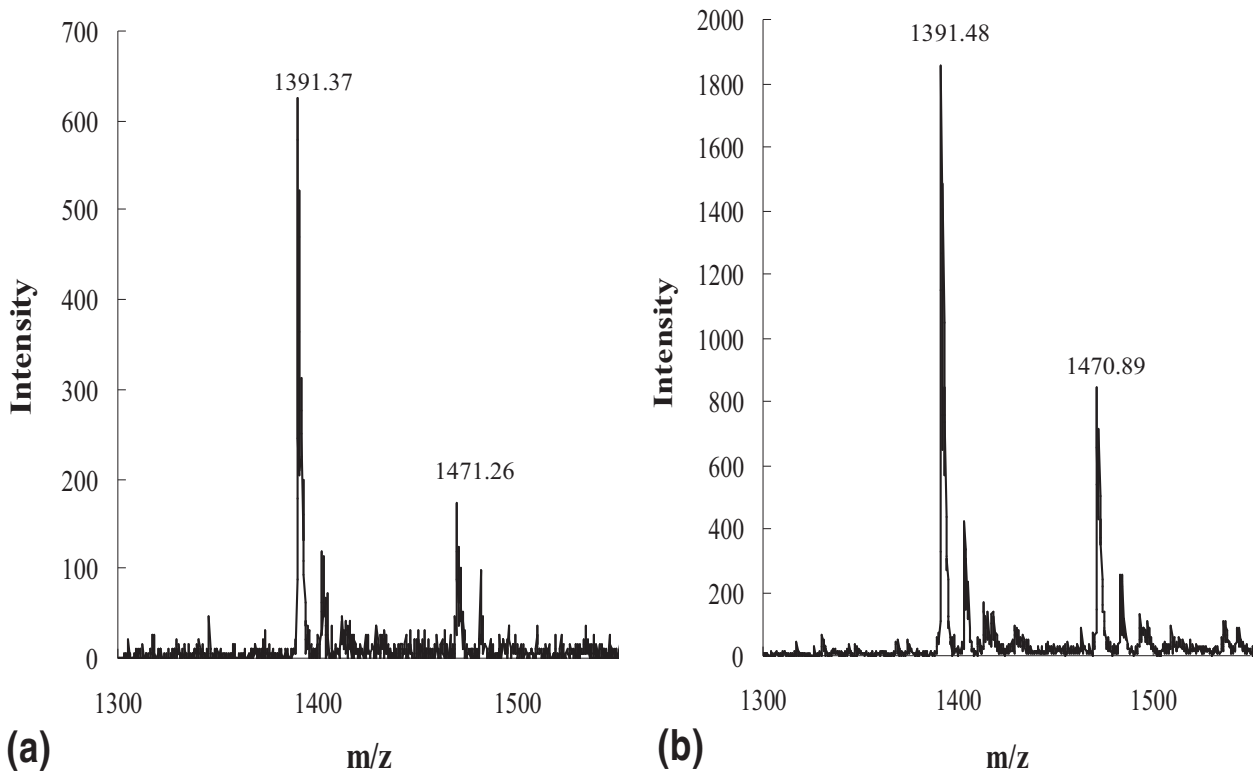

Figure 3. Typical MALDI-TOF mass spectra obtained from phosphorylation of the c-Scr substrate with brain tissue lysate using a CHCA matrix prepared with (b) or without (a) diammonium citrate.

and $60 \mu \mathrm{M})$ with the B16 cell lysate. The phosphorylation ratio in concentrations of 15,30 , and $60 \mu \mathrm{M}$ was $40.7,39.3$, and $15.9 \%$, respectively, in the CHCA matrix with diammonium citrate, but $51.2,32.2$, and $10.8 \%$ without diammonium citrate, respectively. With the addition of diammonium citrate, the ratio decreased in concentrations of $15(P<0.1)$ and $60 \mu \mathrm{M}(P<0.5)$, but increased in $30 \mu \mathrm{M}(P<0.5)$. These results show that if the concentration of the substrate is optimized, the application of diammonium citrate can elevate the detection sensitivity for phosphorylated peptides.

In addition, we examined whether the addition of diammonium citrate to the CHCA matrix affects the detection of the phosphorylated peptide using tissue lysate. The addition of diammonium citrate to CHCA showed an enhanced ionization of the phosphorylated peptide, and this peak intensity was greater than that obtained for CHCA only (Figure 2a-d). Specifically, the addition of diammonium citrate to the CHCA matrix elevated the detection sensitivity for the small peaks associated with the phosphorylated peptide, helping to distinguish them from the background noise (Figure 2c and d). In addition, the phosphorylation of a c-Src substrate for brain tissue lysate samples produced a higher peak in the presence of diammonium citrate, compared when no diammonium citrate was present in the CHCA matrix (Figure 3). Both Figures 2 and 3 showed a high signal-to-noise ratio in the presence of diammonium citrate, leading to an elevated detection sensitivity for phosphorylated peptides. These results suggest that the addition of diammonium citrate to the CHCA matrix may be of benefit for the detection of small phosphorylation peaks if the peptide concentration is sufficient.

The identification of phosphorylated peptides or proteins for certain protein kinases is essential for the characterization of, or search for, substrate proteins for enzymes. The identification process will also be important in explorations for new drugs [12, 13, 18, 19]. The application of diammonium citrate to MALDI-TOF mass spectrometry technique may be useful for identifying phosphorylated peptides or proteins for certain protein kinases.

\section{Acknowledgments}

This work was supported by CREST, Japan Science and Technology Corporation, a grant-in-aid for Scientific Research from the Ministry of Education, Science, Sports, and Culture in Japan, and a grant-in-aid for Scientific Research from the Ministry of Health, Labor, and Welfare.

\section{References}

1. Rozengurt, E., Signal transduction pathways in the mitogenic response to $G$ protein-coupled neuropeptide receptor agonists. J. Cell. Physiol. 1998, 177, 507-517.

2. Biondi, R. M.; Nebreda, A. D., Signalling specificity of Ser/Thr protein kinases through docking-site-mediated interactions. Biochem. J. 2003, 372, 1-13.

3. Roskoski Jr., R., Src protein-tyrosine kinase structure and regulation. Biochem. Biophys. Res. Commun. 2004, 324, 1155-1164.

4. Coligan, J. E.; Dunn, B. M.; Speicher, D. W.; Wingfield, P. E., Mass spectrometry. In Current protocols in protein science; John Wiley and Sons, Inc.: Indianapolis, IN, 1995

5. Liu, Z.; Schey, K. L., Optimization of a MALDI TOF-TOF mass spectrometer for intact protein analysis. J. Am. Soc. Mass. Spectrom. 2005, 16, 482-490.

6. Asara, J. M.; Allison, J., Enhanced detection of phosphopeptides in matrix-assisted laser desorption/ionization mass spectrometry using ammonium salts. J. Am. Soc. Mass Spectrom. 1999, 10, 35-43.

7. Cohen, L.; Chait, B. T., Influence of matrix solution conditions on the MALDI-MS analysis of peptides and proteins. Anal. Chem. 1996, 68, 31-37.

8. Smirnov, I. P.; Zhu, X.; Taylor, T.; Huang, Y.; Ross, R.; Papayanopoulos, I. A.; Martin, S. A.; Pappin, D. J., Suppression of $\alpha$-cyano-4-hydroxycinnamic acid matrix clusters and reduction of chemical noise in MALDITOF mass spectrometry. Anal. Chem. 2004, 76, 2958-2965. 
9. Yang, X.; Wu, H.; Kobayashi, T.; Solaro, J.; van Breemen, R. B., Enhanced ionization of phosphorylated peptides during MALDI TOF mass spectrometry. Anal. Chem. 2004, 76, 1532-1536.

10. Kang, J. H.; Toita, R.; Jiang, Y.; Niidome, T.; Katayama, Y., Simultaneous analysis of phosphorylated peptides by MALDI-TOF MS. Chromatographia 2006, 63, 595-598.

11. Newton, A. C., Regulation of protein kinase C. Current Opin. Cell. Biol. 1997, 9, 161-167.

12. Stabel, S.; Parker, P. J., Protein kinase C. Pharmacol. Ther. 1991, 51, 71-95.

13. Hug, H.; Sarre, T., F Protein kinase C isoenzymes: Divergence in signal transduction? Biochem. J. 1993, 291, 329-343.

14. Nakashima, S., Protein kinase C $\alpha(\mathrm{PKC} \alpha)$ : Regulation and biological function. J. Biochem. 2002, 132, 669-675.

15. Biscardi, J. S.; Ihsizawar, R. C.; Silva, C. M.; Parsons, S., Tyrosine kinase signaling in breast cancer epidermal growth factor receptor and c-Src interactions in breast cancer. Breast Cancer Res. 2000, 2, 203-210.

16. Rosen, N.; Bolen, J. B.; Schwartz, A. M.; Cohen, P.; DeSeau, V.; Israel, M. A., Analysis of pp $60^{\mathrm{c}-\mathrm{src}}$ protein kinase activity in human tumor cell lines and tissues. J. Biol. Chem. 1986, 261, 13754-13759.

17. Frame, M. C., Src in cancer: Deregulation and consequences for cell behavior. Biochim. Biophys. Acta 2002, 1602, 114-130.

18. Oishi, J.; Kawamura, K.; Kang, J. H.; Kodama, K.; Sonoda, T.; Murata, M.; Niidome, T.; Katayama, Y., An intracellular kinase signalresponsible gene carrier for disordered cell-specific gene therapy. J. Control Release 2006, 110, 431-436.

19. Kang, J. H.; Jiang, Y.; Toita, R.; Oishi, J.; Kawamura, K.; Han, A.; Mori, T.; Niidome, T.; Ishida, M.; Tatematsu, K.; Tanizawa, K.; Katayama, Y.,
Phosphorylation of Rho-Associated Kinase (Rho-Kinase/ROCK/ROK) substrates by protein kinases A and C. Biochimie 2007, 89, 39-47.

20. Inamori, K.; Kyo, M.; Nishiya, Y.; Inoue, Y.; Sonoda, T.; Kinoshita, E. Koike, T.; Katayama, Y., Detection and quantification of on-chip phosphorylated peptides by surface plasmon resonance imaging techniques using a phosphate capture molecule. Anal. Chem. 2005, 77, 3979-3985.

21. Han, A.; Sonoda, T.; Kang, J. H.; Murata, M.; Niidome, T.; Katayama, Y., Development of a fluorescence peptide chip for the detection of caspase activity. Comb. Chem. High Throughput Screen. 2006, 9, 21-25.

22. Kang, J. H.; Katayama, Y.; Han, A.; Shigaki, S.; Oishi, J.; Kawamura, K.; Toita, R.; Han, X. M.; Mori, T.; Niidome, T., Mass-tag technology responding to intracellular signals as a novel assay system for the diagnosis of tumor. J. Am. Soc. Mass Spectrom. 2007, 18, 106-112.

23. Songyang, Z.; Carraway, K. L.; Eck, M. J.; Harrison, S. C.; Feldman, R. A.; Mohammadl, M.; Schessinger, J.; Hubbard, S. R.; Smith, D. P.; Eng, C.; Lerenzo, M. J.; Ponder, B. A. J.; Mayer, B. J.; Cantley, L. Catalytic specificity of protein tyrosine kinases is critical for selective signaling. Nature 1995, 373, 536-539.

24. Carrasco, S.; Merida, I., Diacylglycerol, when simplicity becomes complex. Trends Biochem. Sci. 2007, 32, 27-36.

25. Nishizuka, Y., Protein kinase $C$ and lipid signaling for sustained cellular responses. FASEB J. 1995, 9, 484-496.

26. Menezes, L. C.; Pudles, J., Specific phosphorylation of yeast hexokinase induced by xylose and ATPMg. Arch. Biochem. Biophys. 1977, 178, 34-42.

27. DiSalvo, J.; Jiang, M. J., The ATPMg-dependent phosphatase is present in mammalian vascular smooth muscle. Biochem. Biophys. Res. Commun. $1982,108,534-540$. 